\title{
Modeling Geothermal Energy Efficiency from Abandoned Oil and Gas Wells to Desalinate Produced Water
}

\author{
Amin Kiaghadi ${ }^{a}$, Rose S. Sobel ${ }^{a}$, Hanadi S. Rifai ${ }^{b^{*}}$ \\ ${ }^{a}$ Doctoral Candidate, Civil and Environmental Engineering, University of Houston, Houston, \\ TX 77204-4003, USA \\ $\mathrm{b}^{*}$ Professor and corresponding author, Civil and Environmental Engineering, University of \\ Houston, 4726 Calhoun, Houston, TX 77204-4003; rifai@uh.edu; (713) 743-4271 (Fax: (713) \\ $743-4260)$
}

\begin{abstract}
This study investigated the use of low temperature geothermal resources to convert salty produced water into a freshwater resource. The research retrofits soon-to-be-shut-down oil and gas wells as geothermal wells, simultaneously overcoming drilling costs and scale formation by using a freshwater closed loop system for thermal energy delivery. Heat transfer modeling was combined with water treatment thermodynamics to develop a predictive tool that can be used to estimate daily deliverable treated water. Results indicated that the developed model was most sensitive to well depth, geothermal gradient, and total dissolved solids in the produced water. Results also indicated that a $4,000 \mathrm{~m}$ deep well with a geothermal gradient of $0.05^{\circ} \mathrm{C} / \mathrm{m}$ can successfully treat produced water with as high as $170,000 \mathrm{mg} / \mathrm{L}$ total dissolved solids and still deliver almost $600,000 \mathrm{~L}$ of clean water per day. An illustrative demonstration indicated that in the Eagle Ford Shale in Texas, more than $60 \%$ of the drilled basin area can deliver at least half a million liters of treated water daily under ideal conditions. This is particularly meaningful as Texas experiences extended periods of drought and the treated produced water would represent a new and resilient source of water.
\end{abstract}

Keywords: Heat Transfer, Water Treatment, Total Dissolved Solids, Shale, Permian Basin, Eagle Ford Shale 


\section{Introduction}

Population growth and a changing climate will increase global water demand and costs while decreasing water availability $[1,2]$. This motivates an almost universal call to action to ensure the sustainability of water. Surface and groundwater resources are increasingly stressed [3], necessitating the introduction of new freshwater sources. Desalination of seawater [4] and water produced from oil and gas formations [5] represent promising new streams of freshwater. Produced water is co-generated during oil and gas extraction activities over the lifetime of a production well. Produced water varies greatly in quality and quantity [6] but generally contains large concentrations of total dissolved solids (TDS), necessitating desalination, as well as dissolved and dispersed oil components, other dissolved formation minerals, production chemicals, and dissolved gases [7]. Produced water is typically perceived as a waste stream, and generally disposed of via deep well injection. However, the almost 21 billion barrels ( 2.5 trillion liters) of produced water extracted annually can be beneficially reused as a useful by-product or a salable commodity $[8,9]$.

The handling of produced water, including the choice of desalination method, and the quality of the treated water depend on: i) the composition and quantity of produced water; ii) the location of oil and gas wells; and iii) the availability of resources [10,11]. Previous studies have established that produced water can be successfully treated using existing desalination technologies, and converted from a waste to a freshwater source. Cakmakci et al. [12] and Melo et al. [13] used Nano-Filtration and Reverse Osmosis (RO) to treat produced water in Turkey and Brazil, respectively, and reported satisfactory results. Guirgis et al. [14] investigated the use of tubular ceramic membranes in removing oil and grease from produced water and reported $95 \%$ efficiency. Importantly, the most energy intensive component of produced water to treat is the 
TDS content, which can range from 30,000 to $300,000 \mathrm{mg} / \mathrm{L}[6,15,16]$. Thermal and membrane separation desalination processes are presently the two most successful commercial water desalination approaches. For produced water with high TDS levels $(>70,000 \mathrm{mg} / \mathrm{L})$, thermal separation is preferable because of the low efficiency and the fouling challenges associated with membrane desalination [17].

While the development of advanced desalination technologies has accelerated, the key remaining barrier is the cost of powering desalination units, which can make up as much as $60 \%$ of the total treatment cost [17-19]. This large energy demand can be attributed to elevated TDS levels along with the desire for large recovery ratios [20, 21]. For thermal based separation methods, the quality of the heat source (higher temperature) is a key factor in desalination efficiency [22]. Accordingly, the challenge in treating produced water is to reduce the energy cost component sufficiently to be competitive with conventional disposal costs and to do so in a manner that is environmentally beneficial and with minimal infrastructure requirements. Thus, integration of renewable energy systems such as solar, wind, wave, waste heat, and geothermal with desalination is a natural and strategic course of action. It can potentially overcome cost and regulatory barriers associated with the disposal of produced water and provide a resilient and drought resistant source of clean water to meet water demands for multiple uses from hydraulic fracturing to agriculture $[23,24]$.

Recently, newer technologies that utilize low-temperature heat have been developed: Membrane Distillation (MD) which combines thermal and membrane distillation processes [25], and Adsorption Desalination (AD) which can provide potable water and cooling energy at the same time $[26,27]$. Such technologies provide the opportunity to use low temperature heat sources supplied by renewable sources to treat produced water with high TDS levels. Currently, 
using solar energy to power such desalination units is the most common technology.

Meindertsma et al. [28] reported solar energy as the most reliable and available renewable energy source for desalination in Israel. Ghaffour et al. [29] developed a solar-powered AD facility to treat seawater. However, geothermal energy output is more stable compared to other renewable energy sources such as solar and wind energy [29, 30] and, as noted by Sablani et al. [30], does not require thermal storage. Geothermal resources above $150^{\circ} \mathrm{C}$ are typically used for electric power generation [31,32], however, resources with lower temperatures can be used to power desalination units (such as $\mathrm{AD}$ and/or $\mathrm{MD}$ ), representing a new application of this resource. Geothermal energy can be used to directly heat produced water in thermal based desalination units, or to generate electricity for operating Reverse Osmosis (RO) units [32, 33]. Missimer et al. [34] and Ghaffour et al. [29] combined solar energy with geothermal energy and developed a hybrid approach to desalinate seawater. Missimer et al. [35] demonstrated two successful strategies to desalinate seawater using geothermal energy. They used the latent heat from their geothermal electricity generation site to power a coupled Multiple Effect Distillation (MED)-AD system, and diverted some of the generated electricity to power an RO system.

Geothermal heat plants most often operate by injecting water in one well, and extracting heated water in a separate production well. A longer contact time of heating water with the formation will give higher extracted water temperatures at the production well [36]. Though a renewable energy source, the conventional method of drilling geothermal wells and extracting energy still presents challenges that include drilling costs and scale formation. A one-hole geothermal system reduces capital costs, while using existing wells, drilled during oil and gas exploration, is even more economical [37]. In brief, the mechanism for one-hole geothermal heat extraction involves working fluid injection into the annular zone between the well tubing and 
casing and extraction of heated fluid through the tubing [37-39]. Insulation of the tubing prevents heat loss while the heated fluid is pumped to the surface.

The use of abandoned oil and gas wells for harnessing geothermal energy has garnered attention and support over the past decade. Kujawa et al. [37] assessed the possibility of extracting geothermal energy from an existing oil well and developed a computanional model to calculate the geothermal heat flux. They reported a heat flux of $140 \mathrm{KW}$ and working fluid surface temperature of $86.6^{\circ} \mathrm{C}$ for a four $\mathrm{km}$ well with a flow rate of $2 \mathrm{~m}^{3} / \mathrm{hr}$. The authors also investigated the effect of different insulating materials on the extracted fluid temperature. $\mathrm{Bu}$ et al. [38] developed a heat transfer model and conducted a parametric study to optimize one-hole geothermal well operational variables. They concluded that the working fluid flow rate and geothermal gradient (the rate of temperature increase with depth) are the key variables affecting the temperature of extracted fluid and net generated power. Davis and Michaelides [40] and Han and $\mathrm{Yu}[41]$ found similar results and reported well depths and geothermal gradients as the most important variables. Templeton et al. [42] developed a more complex heat transfer model using the finite element model FlexPDE. The results for generated power $(\mathrm{kW})$ were $60 \%-80 \%$ lower than the ones reported in Kujawa et al. [37], and Bu et al. ( [38]. A similar study undertaken by Wight and Bennett [39] showed potential electricity generation of 109-630 kW using abandoned oil and gas wells. Cheng et al. [43] developed a one dimensional model (in the vertical or z direction) based on radial heat flow using Rameys' definition (a simple analytical equation for wellbore temperatures based on heat balance), and fluid energy equations. They compared different working fluids and reported R134a and R245fa as the best fluids for geothermal power generation using abandoned oil wells. 
It is noted that almost all of the studies supporting the use of abandoned wells for harnessing geothermal energy have focused on electricity generation [40, 43, 44]. However, energy loss due to low efficiencies in power generation and transmission, accompanied by the fact that most abandoned oil and gas wells are located in remote areas without proper electrical transmission infrastructure, makes this idea less favorable. The application of geothermal energy for desalination, however, is clearly a promising alternative to electricity generation [33]. The repurposing of expiring oil and gas wells (referred to as decommissioned wells) for geothermal powered desalination also benefits from other existing infrastructure such as pipelines, pumps, and pretreatment facilities.

This paper investigates the feasibility of using geothermal energy from decommissioned wells to power desalination of produced water and generate clean water. The research proposes a novel integration of three concepts at the water-energy nexus that, to the best of the knowledge of the authors, have not been presented as such in the general literature: (1) reclaiming produced water from a waste to an asset via existing desalination treatment technologies; (2) retrofitting decommissioned wells for use as geothermal wells to power desalination treatment units; and (3) creating a freshwater based circulation loop to extract heat from the retrofitted geothermal well. The proposed approach of retrofitting decommissioned wells surmounts the cost of drilling a geothermal well and presents opportunities for reducing the environmental footprint of oil and gas extraction. Such wells, if otherwise shut down, would contribute to the rising epidemic of abandoned wells and their associated environmental impacts including emerging evidence of unintentional, but relatively significant, methane emissions [45]. Freshwater, as the working fluid, will reduce/eliminate the potential for scale formation that hinders the use of geothermal energy. Finally, treating produced water creates new freshwater resources that might be critically 
needed in times of drought and alleviates some of the adverse environmental impacts of disposal of produced water.

The primary challenges from a technological standpoint include 1) demonstrating that retrofitted geothermal wells can provide the heat required for desalination units; and 2) identifying decommissioned wells that are well suited for this purpose. A key novelty presented in this paper to address the first challenge involves the coupling of an existing heat transfer model [43] with the thermodynamics of energy requirements for water treatment [21]. Equally novel is the approach for addressing the second challenge. A geospatial tool applies the output of the heat transfer model to calculate the volume of deliverable treated water that can be realized, based on geothermal considerations and oil and gas activities in existence in a specified location. Importantly, a key outcome from this research; illustrated for Texas oil and gas formations, is the ability to predict the potential volumes of treated water that can be generated using geothermal energy under different scenarios of well efficiencies, as well as the potential locations that may be best suited for retrofitting.

\section{Methodology}

The methodology used in the study included four inter-related components. The first section describes the overall mechanism for geothermal heat extraction (Section 2.1). The second component (Section 2.2) modifies an existing heat transfer model to simulate heat transfer in the retrofitted geothermal well $[38,43]$ while the third (Section 2.3) uses thermodynamic first and second laws to establish the feasibility and output of treated produced water generated using theoretical desalination energy requirements (independent of desalination technology). In other words, the results from the heat transfer model are used as input for the thermodynamic equations in order to calculate the theoretical volume of deliverable treated water. Lastly 
(Section 2.4), statistical methods and Geographic Information System (GIS) based databases were coupled with the heat transfer models to calculate the deliverable treated water based on geologic conditions, well depth, geothermal gradient, and produced water TDS levels in a given region. Texas was used in this fourth component for illustration purposes.

\subsection{Mechanism of Heat Extraction from Retrofitted Geothermal Wells}

In an oil field, tank batteries that separate oil, gas and produced water are located about $1.5 \mathrm{~km}$ from producing wells. Produced water is piped to the desalination treatment site, and pretreated for solids and bacteria. In the proposed conceptual model, desalination of the pre-treated produced water would be powered by thermal energy obtained from retrofitting a decommissioned oil and gas well into a closed-system geothermal well.

The schematic in Figure 1 illustrates the mechanism for geothermal heat extraction from retrofitted geothermal wells (see also [37-39]). The working fluid is injected in the annular zone between the well tubing and casing and extracted through the tubing. The working fluid, clean water in this case, constitutes a separate stream that is continuously extracted and re-injected from the geothermal well to power the desalination unit. The clean water will be supplemented with anti-bacterial and anti-corrosive additives to maintain working fluid performance. Importantly, produced water is never injected into the retrofitted geothermal well thereby alleviating the formation of scale.

Once injected, the working fluid flows down, and is gradually heated by the surrounding rocks. When the fluid reaches the bottom of the well, its flow direction is reversed, and the hot fluid ascends through the insulated tubing up to the surface. The temperature drop in upward flow can be minimized via implementation of thermal insulation between well layers/components. The resulting hot extracted fluid is routed to power the desalination unit 
where its heat is extracted and the resulting colder water will be re-circulated back to the geothermal well. An important consideration for the retrofitted geothermal well is the issue of thermal efficiency and whether sufficient heat can be generated to power desalination. The next section presents thermodynamic model development that allows the calculation of the extracted working fluid temperature.

\subsection{Heat Transfer Modeling in a Geothermal Well}

A heat transfer model is needed to determine the extracted fluid temperature and total daily extractable heat from a retrofitted geothermal well. In this study, a simple heat transfer model was selected to allow the coupling of the heat model with the geospatial model (described in Section 2.4 and illustrated in Section 2.5) and to reduce computational costs and provide comparability and transparency for future work. For the given system described above and shown in Figure 1, heat flow can be calculated from the following equation [46, 47]:

$\dot{Q}=\rho_{w f} u_{w f} \pi\left(R_{w}^{2}-\left(r_{t u b}+t_{i n s}\right)^{2}\right) C_{w f}\left(T_{E x t}-T_{I n j}\right)$

Where $\dot{Q}$ : Total heat flow $(\mathrm{KW}) ; \rho_{w f}$ : Injection fluid density $\left(\mathrm{kg} / \mathrm{m}^{3}\right) ; u_{w f}:$ Injection velocity (m), assumed to be constant at different depths in this research; $R_{w}$ : Internal radius of the well (m); $r_{t u b}$ : External radius of tubing (m); $t_{i n s}$ : Thickness of the insulating layer (m); $C_{w f}$ : Specific heat of working fluid $(\mathrm{KJ} / \mathrm{Kg} \cdot \mathrm{K}) ; T_{E x t}$ : Extracted working fluid temperature (K); and, $T_{I n j}$ : Injected fluid temperature (K).

All the variables in equation (1) are known values related to well properties or operational conditions except $T_{E x t}$, the extracted working fluid temperature. To estimate $T_{E x t}$, the authors adopted a simplified version of the Cheng et al. [43] radial heat transfer model (based on Ramey's definiton) for its simplicity, comparability, and transparency of model inputs. The heat transfer model employes several assumptions: 
- The model is one dimensional (in the vertical or $\mathrm{z}$ direction)

- Formation heat will transfer to the injected fluid as the fluid moves downward and this energy will be used to power desalination

- Constant temperature at infinite distance from the well axis (i.e. formation temperature)

- Ideal insulation around the tubing such that there would be no heat exchange between the working fluid in the extraction and injection areas. Therefore, the extracted fluid temperature at the surface, $T_{E x t}$, can be set equal to the temperature at the bottom of the retrofitted geothermal well.

- Constant working fluid velocity over the depth of the well.

- Constant specific heat of water at different temperatures.

- Constant well structure (radius of casing and tubing) over the depth of the well

- Only lateral heat exchange between the formation and the injected water is considered, while transferable heat from the well bottom to the injected water was neglected.

The model was vertically discretized into computational cells, $(\Delta z)$, of $100 \mathrm{~m}$ vertical extent, so the number of cells per run increased with well depth. At each computational cell in the 1-D vertical dimension $(\Delta z)$, three main equations from Cheng et al. [43] were solved with slight modifications under constant operational conditions for $T_{w f o u t}$, the temperature leaving each cell; which serves as the $T_{w f i n}$, the temperature entering each cell, for the next computation cell below (in the vertical or $\mathrm{z}$ direction). The last cell, at the base of the well, gives the desired quantity, $T_{E x t}$, in Equation (1):

$\Delta \dot{Q}_{\text {cell }} f(t)+2 \pi \lambda_{e} T_{f} \Delta z=2 \pi \lambda_{e} T_{f i} \Delta z$

$\Delta \dot{Q}_{\text {cell }}=2 \pi R_{w} h_{w f} \Delta z\left(T_{f}-T_{w f i n}\right)$ 
$\Delta \dot{Q}_{c e l l}=\rho_{w f} A_{i n j} C_{w f} u_{w f}\left(T_{w f o u t}-T_{w f i n}\right)$

In which, $\Delta \dot{Q}_{\text {cell }}$ : Changes in the rate of heat flow (W) with respect to changes in depth $(\Delta z)$ for each cell; $f(t)$ : Transient heat conduction function with operational time, thermal diffusivity of the formation, and radius of the well as independent variables; $\lambda_{e}$ : Thermal conductiviy of the formation $(\mathrm{W} / \mathrm{m} \cdot \mathrm{K}) ; T_{f}$ : Temperature of the heat exchanger (well wall) and formation interface $(\mathrm{K}) ; \Delta z$ : Vertical extent of each cell $(\mathrm{m})$ which was set at $100 \mathrm{~m} ; T_{f i}$ : Formation temperature at infinite distance (K) that can be calculated as $T_{f i}=T_{\text {surf }}+\nabla e z$ where $T_{\text {surf }}$ is the surface temperature $(\mathrm{K}) ; \nabla e$ is the geothermal gradient $\left({ }^{\circ} \mathrm{C} / \mathrm{m}\right)$ and $z=n \Delta z$ is the computational cell depth (m) and $\mathrm{n}$ is the number of computational cells (total depth/ $\Delta z$ ); $h_{w f}$ : Convective heat transfer coefficient which is a function of the working fluid, well structure properties, and injection velocity [48] $T_{w f i n}$ : Fluid temperature entering the cell (K); and $T_{w f o u t}$ : Fluid temperature exiting the cell $(\mathrm{K})$.

The transient heat conduction function, $f(t)$, accounts for unsteady heat transfer from the surrounding formations [37]. For a relatively long injection time ( $>7$ days), Ramey's approximate transient function can be assumed [49]:

$f(t)=\ln \left(2 \sqrt{\tau_{D}}\right)-0.2886$

Where $\tau_{D}=\alpha_{e} \tau / r_{\text {extub }}{ }^{2}$ represents dimensionless time; $\alpha_{e}$ is the thermal diffusivity of the formation $\left(\mathrm{m}^{2} / \mathrm{s}\right) ; \tau$ is operational time (d); and $r_{\text {extub }}=r_{t u b}+t_{\text {ins }}$ is the radius of the well from the center of the well to the outside of the insulating layer (m).

The convective heat transfer coefficient, $h_{w f}$, for the turbulent fluid flow inside the well can be calculated as [43]:

$h_{w f}=\frac{0.023 \lambda_{w f} R e^{0.8} \operatorname{Pr}^{0.4}}{d_{e}}$ 
Where $\lambda_{w f}$ is the thermal conductivity of the fluid (W/m.K); Re $=\rho_{w f} u_{w f} d_{e} / \mu_{w f}$ is the Reynolds number; $\operatorname{Pr}=C_{w f} \mu_{w f} / \lambda_{w f}$ is the Prandtl number; $\mu_{f}$ is the fluid's viscosity (N.s $/ \mathrm{m}^{2}$ ); and $d_{e}=2\left(R_{W}-\left(r_{t u b}+t_{i n s}\right)\right)$ is the injection hydraulic diameter $(\mathrm{m})$.

As can be seen in equations (2) through (4), there are 4 unkowns $\left(\Delta \dot{Q}_{\text {cell }}, T_{f}, T_{w f i n}\right.$, and $\left.T_{w f o u t}\right)$ with only three equations. To solve this problem, it is assumed that the fluid temperature entering the first cell $\left(T_{w f i n}\right)$ at the surface is known and is equal to $T_{\text {Inj }}$, injected fluid temperature, and that the fluid temperature exiting the first cell $\left(T w_{\text {fout }}\right)$ will be assigned to the $T_{w f i n}$ for the next cell and so on for the entire well depth. Once $T w_{\text {fout }}$ for the last cell at the bottom of the well is obtained (which is equal to $T_{E x t}$ in equation (1)), total heat flow from the retrofitted geothermal well (KW) can be calculated. The developed model was run using a code that was developed in MATLAB.

\subsection{Deliverable Volume of Treated Water via Desalination using Geothermal Energy}

To calculate the volume of treated water that can be delivered using the heat generated from a given geothermal well, the least heat required for treatment at different TDS levels is needed.

$V_{\text {clean }}=\frac{\dot{Q} \times 24(h / \text { day })}{\dot{H}_{\text {least }}}$

Where, $V_{\text {clean }}$ is the daily volume of deliverable clean water ( $\mathrm{m}^{3} /$ day); and $\dot{H}_{\text {least }}$ is the theoretical least heat of separation $\left(\mathrm{kWh} / \mathrm{m}^{3}\right.$ of clean water). The least heat of separation is the theoretical heat required to separate salts from the water given by the first and second laws of thermodynamics in terms of the Gibbs free energy. $\dot{H}_{\text {least }}$ can be calculated using the equation suggested by Mistry and Lienhard (2013) [22]: 
$\dot{H}_{\text {least }}=\left(1-T_{\text {prod }} / T_{\text {ext }}\right)^{-1} \dot{W}_{\text {least }}$

Where, $\dot{W}_{\text {least }}$ is the theoretical least work of separation, $\left(\mathrm{kWh} / \mathrm{m}^{3}\right.$ of clean water); $T_{\text {prod }}$ is the produced water temperature $(\mathrm{K})$, and $T_{\text {ext }}$ is the hot source water temperature [22]; i.e. the output from the heat transfer model described in Section 2.2. Theoretical $\dot{W}_{\text {least }}$ can be calculated based on the activity coefficients for the feed water (produced water), the product water (treated water), and the concentrated brine. The activity coefficient of each fluid is a function of its TDS level, mineral composition, and temperature. Theil et al. [21] reported the least work of separation and the recovery ratio for three representative produced water samples with various TDS levels. The reported least work values for the Permian Basin (average TDS of $224,000 \mathrm{mg} / \mathrm{l}$ ), Marcellus Shale (average TDS of $170,000 \mathrm{mg} / \mathrm{l}$ ), Nova Scotia (average TDS of $63,000 \mathrm{mg} / \mathrm{l}$ ), and an $\mathrm{NaCl}$ mass solution with TDS of $36,000 \mathrm{mg} / 1$ were $8.31,6.27,4.58$, and 2.2 $\mathrm{KWh} / \mathrm{m}^{3}$ clean water, respectively $[20,21]$. These values were adopted in the study and a linear interpolation was used for intermediate TDS levels.

As can be seen from equation (8), the ratio between the produced water and the extracted fluid temperature is a key factor in determining the least heat of separation, thereby suggesting that efficiency of the treatment process is dictated by the second law of thermodynamics. A colder produced water and hotter working fluid will lead to a lower required heat [22].

\subsection{Sensitivity Analysis of Heat Transfer and Deliverable Water Volume}

The heat transfer modeling described in Section 2.2 and the deliverable volume of freshwater via desalination are interconnected and a function of several variables that are location specific (e.g., well depth, TDS content of produced water, etc.). In order to demonstrate feasibility of the proposed conceptual model of treating produced water using geothermal energy from decommissioned oil and gas wells, a sensivity analysis was undertaken that evaluates the 
effect of several variables listed in Table 1. These variables can be categorized into four groups: formation properties, well properties, working fluid properties, and operational variables. The values shown in Table 1 represent a base scenario that was defined based on values from the literature and/or assumptions for actual operational conditions.

In this research, water was the working fluid; though other fluids may be investigated in future work. For the parameter estimates based on available data, the range of obtained data was used for sensivity analyses and for those with no data, a $\pm 50 \%$ variation from the base scenario was used. The sensitivity of the model to operational time, $\tau$, was investigated for a range of 1 day to 20 years. Based on equation (1), increasing the injection velocity $\left(u_{w f}\right)$ will increase heat flow, and consequently the deliverable water volume. However, a higher injection velocity will lead to a lower working fluid temperature because of shorter exposure time between the well wall and the working fluid. Previous studies reported a working fluid injection velocity (flow rate) between $0.01 \mathrm{~m} / \mathrm{s}$ and $0.1 \mathrm{~m} / \mathrm{s}$, and Bu et al. [38] reported $0.03 \mathrm{~m} / \mathrm{s}$ as the optimized rate. An optimization algorithm was applied to determine the optimal injection velocity to obtain the highest deliverable treated water for the base scenario. MATLAB provides a standard built-in Genetic Algorithm optimization tool using the Stochastic Uniform Method. The user-selected settings input to the tool include an upper and lower bounds for injection velocity ( 0.0001 and $0.1 \mathrm{~m} / \mathrm{s}$ ), population size (30), population type (double vector), the maximum number of iterations before the algorithm stops (50), and termination tolerance value for the function (1.0E15). The remaining settings were kept at the default values in MATLAB.

In addition to sensitivity analysis, the model was used to calculate the volume of daily deliverable treated water after one year of operation under typical commonly observed conditions, including 3 different values of well depth (2000, 3000, $4000 \mathrm{~m})$, TDS $(36,000$, 
$63,000,170,000 \mathrm{mg} / \mathrm{L})$ and geothermal gradient $\left(0.03,0.04,0.05^{\circ} \mathrm{C} / \mathrm{m}\right)$. This resulted in twentyseven scenarios that reflected the representative geospatial variation across the U. S. The remaining parameter estimates for the 27 scenarios came from the values listed in Table 1 . The simulated conditions can be compared to the individual basins that are described in Table 2 .

\subsection{Illustrative Feasibility Analysis for Texas}

Several of the variables described in this paper depend on the specific formation and location of the retrofitted geothermal well. Thus, an illustrative analysis was developed to demonstrate the geospatial dependencies that affect feasibility of using geothermal energy to power desalination units. Texas was chosen for the analysis for several reasons including its significant record of oil and gas exploration and production, recent and recurring water stress from drought, geothermal potential, and the increasing demand for agricultural and municipal water from its rapidly expanding population. In 2012, the Railroad Commission of Texas (RRC) reported 270,082 active oil and gas wells that produced more than 608 million barrels of oil and 230 billion cubic meters of natural gas. In the same year, more than 7 billion barrels of produced water were reported; $48 \%$ of which was used for enhanced recovery, $47 \%$ was injected into disposal wells, and only 5\% was deployed for beneficial reuse [9].

As shown in Figure 2, Texas has five major oil and gas formation/basins: the Haynesville/Bossier Shale, the Barnett Shale, the Permian Basin, the Granite Wash Formation, and the Eagle Ford Shale. Figure 2 also shows the locations of vertical wells with depths greater than $300 \mathrm{~m}(\sim 1,000 \mathrm{ft}).[50,51]$.

Assuming: i) a standard radius for casing and tubing (confirmed to have minimal influence via sensitivity analysis, results not shown), and ii) the working fluid is water at an optimized injection velocity; the key parameters in selecting locations for retrofitting wells are 
depth, geothermal gradient, formation thermal conductivity, formation diffusivity, and TDS of the produced water. The complete drilled well data record (1920-2016), including vertical well locations and depths, were compiled from DrillingInfo databases [51]. Directional (unconventional) wells were not used in this study since the vertical and horizontal lengths were only reported as a combined value. A total of 234,842 vertical wells with depths greater than 300 $\mathrm{m}(1,000 \mathrm{ft}$.$) were analyzed. Geothermal gradients and thermal conductivities of the formation$ for 11,653 wells were obtained from the SMU National Geothermal Data System [52]. Finally, TDS data was obtained from U.S. Geological Survey National Produced Waters Geochemical Database [53]. No data were found for thermal diffusivity of the formation; a constant value of $3.13 \mathrm{E}-7 \mathrm{~m} / \mathrm{s}$, reported by Jong van Lier and Durigon [54], was used.

Table 2 summarizes the well count, depths, TDS levels and geothermal gradients from the well data record by formation. It is noted that Table 2 represents the only comprehensive assessment of such basin conditions. The Granite Wash Formation has the highest median and average well depth, while the Barnett Shale has the shallowest wells. Very deep wells (depth > 4,500 m) are found at the southwest corner of the Permian Basin, the eastern and southern portions of the Eagle Ford Shale, the eastern part of the Haynesville/Bossier Shale, and the center of the Granite Wash Formation. High TDS concentrations are observed in all five formation/basins, but the Eagle Ford Shale has the lowest mean and median TDS levels. The Barnett Shale, on the other hand, has the highest mean and median TDS levels. The sharpest geothermal gradients are observed in the Eagle Ford Shale and Granite Wash Formation respectively, while the Permian Basin has the lowest gradient. Data availability for variation in thermal conductivity was limited and is not reported in Table 2. A $25 \mathrm{~km} \mathrm{x} 25 \mathrm{~km}$ grid of Texas was generated in $\operatorname{ArcMap}^{\mathrm{TM}}$ [55]. Values for depth, TDS, and thermal conductivity data points 
from the sources noted above were joined into the grid cells for statistical analysis. The mean, median, and maximum values for well depth $(h)$, TDS level, and thermal conductivity $\left(\lambda_{\mathrm{e}}\right)$ were calculated for each grid cell containing more than one well. For grid cells with only one well, the reported values were used. A temperature-depth curve was developed to obtain the geothermal gradient, $\nabla e$, for each grid cell from a linear regression of well depth (h) and corresponding temperature at that depth. Average recorded surface temperatures $\left(T_{\text {surf }}\right.$, set at depth $\left.=0 \mathrm{~m}\right)$ were included in the linear regression at reported values or set to $20^{\circ} \mathrm{C}$ when no surface temperature data were available. Among the 1,293 (25 km x $25 \mathrm{~km})$ grid cells covering Texas, 547 contained sufficient data, while the remaining grid cells were located in places with no oil and gas wells or where one of the required data points was missing. The resulting values for the modeled variables (geothermal gradient, well depth, TDS, thermal conductivity) in each of the 547 grid cells were then exported to the heat transfer model in MATLAB.

Three illustrative scenarios were evaluated to estimate treated water delivery based on the observed conditions in each grid cell: i) Mean scenario (average depth, TDS, and conductivity), ii) Max Depth scenario (maximum depth, average TDS, and average conductivity), and iii) Ideal scenario (maximum depth, minimum TDS, and maximum conductivity,). The resulting modeled deliverable treated water volume data were exported to ArcGIS for spatial rendering. It should be noted that new desalination technologies such as $\mathrm{MD}[25]$ and $\mathrm{AD}[26,27]$ can work with a hot working fluid at an evaporator inlet temperature starting between $50-70{ }^{\circ} \mathrm{C}$. For this reason, grid cells were considered "Not Applicable" if the extracted working fluid temperature, $T_{E x t}$, was less than $50^{\circ} \mathrm{C}$. In a few grid cells with only very shallow wells and low geothermal gradients, $T_{I n j}$ was warmer than the temperature at the well base, so these grid cells were also classified as "Not Applicable.” 


\section{Results and Discussion}

\subsection{The Impact of Heat Transfer and Thermodynamics on Deliverable Water Rates}

The heat transfer model (Section 2.2) successfully reproduced the results reported in Cheng et al. [43]. As there is no pilot scale facility for retrofitted geothermal well desalination, a formal validation is not presently possible. The heat transfer results (i.e. extracted working fluid temperature) were compared to results presented Kujawa et al. [37] and Bu et al. [38]. However, due to the use of different sets of equations and the absence of some input data, only values for well structure, geothermal gradient, well depth, injected fluid temperature, and injection velocity were input to the heat transfer model. To compensate, the unreported parameters: formation thermal conductivity, thermal diffusivity of formation, and surface temperature, are included in the sensitivity analysis (see Section 2.4). For a 3,950 m well, with a geothermal gradient of 0.025 $\left({ }^{\circ} \mathrm{C} / \mathrm{m}\right)$, injected fluid temperature of $25^{\circ} \mathrm{C}$, and flow rate of $2 \mathrm{~m}^{3} / \mathrm{h}$ under steady state condition, Kujawa et al. [37] reported $86.6{ }^{\circ} \mathrm{C}$ as the extracted working fluid temperature. Equivalent conditions in this study resulted in a comparable $91.4{ }^{\circ} \mathrm{C}$. Bu et al. [38] simulated a $4,000 \mathrm{~m}$ well, with a geothermal gradient of $0.025\left({ }^{\circ} \mathrm{C} / \mathrm{m}\right)$, injected fluid temperature of $25^{\circ} \mathrm{C}$, and injection velocity of $0.03 \mathrm{~m}^{3} / \mathrm{s}$ and reported $88^{\circ} \mathrm{C}$ as the extracted working fluid temperature after two months of operation. Equivalent conditions in this study resulted in a comparable $85.7^{\circ} \mathrm{C}$. The differences between the outputs of this work and the other models could be a result of missing input data.

The base scenario (\#13 in Table 3) resulted in 146,495 liters of deliverable treated water per day after one year of operation. From the sensitivity analysis shown in Figure 3; depth, geothermal gradient, TDS, and thermal conductivity are the most influential parameters, 
respectively. Depth and geothermal gradient; however, have the greatest impact on deliverable treated water as would be expected because these variables directly reflect formation temperature and available heat for extraction. As discussed previously, higher TDS concentrations increase the amount of thermal energy required for treatment. The system is also quite sensitive to thermal conductivity; however, based on the SMU database [52] the observational range in Texas is limited $(1.85-2.48 \mathrm{~W} / \mathrm{m} \cdot \mathrm{K})$. A larger ratio between the temperature of the extracted working fluid and that of the produced water during treatment will reduce the least heat requirement (see equation (8)). Finally, the model results were least sensitive to thermal diffusivity. Observational values are needed to determine if this parameter varies by more than the $\pm 50 \%$ range used.

Model results for the 27 sensitivity analysis scenarios are also presented in Table 3 with deliverable water rates ranging from near $30,000 \mathrm{~L} /$ day to over 1.7 million L/day. At the maximum output, this is equivalent to the daily residential water demand of more than 5,200 Texas residents (in Texas, per capita residential use is an average of approximately $325 \mathrm{~L} /$ day; [56]. As expected, scenarios with deeper wells, larger geothermal gradients, and lower TDS levels will deliver the greatest volumes of treated water as is reflected in the results shown in Table 3. The least heat required for desalination varied from approximately 8 to $89 \mathrm{KWh}$ per cubic meter of treated water. This enormous difference is the result of different TDS levels and the quality of the heat source (the TDS dependence comes from the least work variable in equation (8).

As discussed in Section 2.4, it was assumed in this study that the injection fluid is water at an optimized injection velocity. The data in Figure 4L illustrate that the injection velocity does not exhibit a linear behavior and has a maximum optimal value (Genetic Algorithm output) of 
$0.0249 \mathrm{~m} / \mathrm{s}(\sim 1.5 \mathrm{~m} / \mathrm{min})$. This is consistent with Bu et al. [38] who reported an optimum injection velocity for a typical decommissioned well on the order of $0.03 \mathrm{~m} / \mathrm{s}$. It should be noted that this optimum value is for the base case scenario, and different scenarios will have different optimum values. Selection of the ideal injection velocity should be based on formation and operational conditions.

The other variable that bears consideration in addition to injection velocities is the operation time, $\tau$, for the geothermal well. Analysis of model results showed a significant water delivery drop in the first year of operation (Figure 4R). The formation is hot initially, but heat flow from the infinite distance to the source eventually reaches an equilibrium. For this reason, the one-year benchmark was chosen for all reported water delivery volumes. To be more specific, in less than a month ( $\sim 27$ days) of operation; the system capacity will drop by half. The declining pace will slow down after the first year; and in year 20, only a $38 \%$ reduction is expected as compared to the end of year 1. A similar effect was reported by Templeton et al. [42]; a rapid drop in the outlet temperature of the working fluid $\left(T_{E x t}\right)$ was observed within the first year of operation of a geothermal well. Nevertheless, and as can be seen in Figure 4R, the generated volumes are significant enough to support use of this technology for treating produced water. Future work would need to consider the rate of generation of produced water with the rate at which the produced water could be treated using geothermal energy.

\subsection{Geospatial Impacts on Deliverable Water Volumes}

\subsubsection{Spatial Variability of Deliverable Treated Water Rates}

Figure 5 and Figure 6 show the spatial variation in deliverable treated water under "Mean" and "Ideal" scenarios, respectively, in Texas. Under the "Mean" scenario, approximately $40 \%$ of all grid cells deliver a minimum of $18,000 \mathrm{~L}$ of clean water per day at the one-year 
benchmark. The corresponding percentages for all formations are approximately $72,56,45,30$, and $2 \%$ of the grid cells in the Granite Wash formation, Eagle Ford Shale, Haynesville Shale, Permian Basin, and the Barnett Shale, respectively. In the "Max" scenario, not pictured, the percentage of grid cells that provide at least $18,000 \mathrm{~L}$ of water per day is much greater: more than $90 \%$ in the Granite Wash and the Eagle Ford, $84 \%$ in the Haynesville Shale, $82 \%$ in the Permian Basin, and 32\% in the Barnet Shale. Similar results were obtained under "Ideal" conditions shown in Figure 6.

The majority of the grid cells in the Eagle Ford Shale, Granite Wash, Haynesville Shale, and Permian Basins provide treated water volumes far exceeding the 18,000 L/day minimum. In the Eagle Ford Shale, the largest basin in Texas, more than $60 \%$ of grid cells can deliver at least half a million liters of treated water daily under the "Ideal" Scenario while approximately $37 \%$ and $7 \%$ of the grid cells can deliver more than one and two million liters of water each day, respectively. Outputs suggest that the majority of the Eagle Ford Shale, along with the southwestern portions of the Permian Basin, and the center of the Granite Wash Formation are the most suited for retrofitting decommissioned oil and gas wells and converting them to geothermal wells that power desalination units to turn produced water into a viable and significant water source. The studied basins also have substantial agricultural land use, which will benefit from additional available water resources. The Barnett Shale and the remainder of the Permian Basin require more careful consideration and collection of additional data (for example, injection velocity, thermal conductivity, thermal diffusivity) to demonstrate the feasibility of using geothermal energy to power water desalination. It should be noted that in all instances, retrofitted geothermal wells may be able to provide sufficient water streams in times of drought and for agricultural and industrial uses and alleviate the stress on surface water and 
groundwater resources. An added benefit is the reduction in potential environmental pollution and earthquakes that may be associated with re-injection of produced water in deep injection wells drilled specifically for this purpose. It is also clear that other environmental benefits would ensue from reducing the number of truckloads of freshwater and produced water that are being transported each day to and from oil and gas production sites.

\section{Conclusion}

Reducing the energy requirements for desalination and the need for deep well injection of produced water streams were demonstrated to be feasible in this work. Treating produced water using energy from retrofitted geothermal wells reduces the cost of drilling wells, improves the efficiency of acquiring geothermal energy, and counteracts the stigma of "abandoning wells". The volumes of treated water that can be generated during the first year of retrofitted geothermal well operation are relatively significant and meaningful treatment capacity can be maintained over many years. The generated clean water represents a constant and resilient source of freshwater that can be used for continued oil and gas operations, agriculture, and to meet nonpotable municipal demands.

The developed models in this research can be enhanced to align cumulative water delivery over time with local (at grid cell resolution) industrial, agricultural, and municipal water needs, and to investigate the interactions between nearby retrofitted geothermal wells. In areas with high quality heat sources, such as the southern Eagle Ford Shale in Texas, it is likely possible to co-generate electricity and heat for desalination. Coupling of these processes enables studies that explore the power-energy-water nexus. 


\section{Acknowledgements}

The research was funded by the Texas Commission on Environmental Quality, the U. S.

EPA, Houston Endowment, and the National Science Foundation (NSF) GK-12 Program Award \#0840889; their support is gratefully acknowledged. Professor Zachary Bray, Dr. Konstantinos

Kostarelos, and Dr. S. Radha Radhakrishnan are acknowledged for their mentorship. Power Across Texas and UH energy are acknowledged for motivating the study. Ali Masoudi is acknowledged for his great feedback on heat transfer modeling. Maria Modelska and Aparna Balasubramani are acknowledged for providing valuable comments on the manuscript.

\section{References}

1. Medellin-Azuara, J., Harou, J.J., Olivares, M.A., Madani, K., Lund, J.R., Howitt, R.E., Tanaka, S.K., Jenkins, M.W. and Zhu, T., Adaptability and adaptations of California's water supply system to dry climate warming. Climatic Change, 2008. 87: p. S75-S90. DOI: $10.1007 / \mathrm{s} 10584-007-9355-\mathrm{z}$.

2. Charlton, M.B. and N.W. Arnell, Adapting to climate change impacts on water resources in England-An assessment of draft Water Resources Management Plans. Global Environmental Change-Human and Policy Dimensions, 2011. 21(1): p. 238-248. DOI: 10.1016/j.gloenvcha.2010.07.012.

3. Carpenter, S.R., E.H. Stanley, and M.J. Vander Zanden, State of the World's Freshwater Ecosystems: Physical, Chemical, and Biological Changes, in Annual Review of Environment and Resources, Vol 36, A. Gadgil and D.M. Liverman, Editors. 2011. p. 7599. DOI: 10.1146/annurev-environ-021810-094524.

4. Smakhtin, V., Ashton, P., Batchelor, A., Meyer, R., Murray, E., Barta, B., Bauer, N., Naidoo, D., Olivier, J. and Terblanche, D., Unconventional water supply options in South Africa - A review of possible solutions. Water International, 2001. 26(3): p. 314-334.

5. Olsson, O., D. Weichgrebe, and K.H. Rosenwinkel, Hydraulic fracturing wastewater in Germany: composition, treatment, concerns. Environmental Earth Sciences, 2013. 70(8): p. 3895-3906. DOI: 10.1007/s12665-013-2535-4.

6. $\quad$ Barbot, E., Vidic, N.S., Gregory, K.B. and Vidic, R.D., Spatial and Temporal Correlation of Water Quality Parameters of Produced Waters from Devonian-Age Shale following Hydraulic Fracturing. Environmental Science \& Technology, 2013. 47(6): p. 2562-2569. DOI: 10.1021/es304638h.

7. Torres, L., O.P. Yadav, and E. Khan, A review on risk assessment techniques for hydraulic fracturing water and produced water management implemented in onshore unconventional oil and gas production. Science of the Total Environment, 2016. 539: p. 478-493. DOI: 10.1016/j.scitotenv.2015.09.030. 
8. Gregory, K.B., R.D. Vidic, and D.A. Dzombak, Water Management Challenges Associated with the Production of Shale Gas by Hydraulic Fracturing. Elements, 2011. 7(3): p. 181-186. DOI: 10.2113/gselements.7.3.181.

9. Veil, J.A., Produced Water Volumes and Management Practices in 2012. 2015: Ground Water Protection Council.

10. Fakhru'l-Razi, A., Pendashteh, A., Abdullah, L.C., Biak, D.R.A., Madaeni, S.S. and Abidin, Z.Z., Review of technologies for oil and gas produced water treatment. Journal of Hazardous Materials, 2009. 170(2-3): p. 530-551. DOI: http://dx.doi.org/10.1016/j.jhazmat.2009.05.044.

11. Estrada, J.M. and R. Bhamidimarri, A review of the issues and treatment options for wastewater from shale gas extraction by hydraulic fracturing. Fuel, 2016. 182: p. 292303. DOI: 10.1016/j.fuel.2016.05.051.

12. Cakmakci, M., N. Kayaalp, and I. Koyuncu, Desalination of produced water from oil production fields by membrane processes. Desalination, 2008. 222(1-3): p. 176-186. DOI: 10.1016/j.desal.2007.01.147.

13. Melo, M., Schluter, H., Ferreira, J., Magda, R., Júnior, A. and de Aquino, O., Advanced performance evaluation of a reverse osmosis treatment for oilfield produced water aiming reuse. Desalination, 2010. 250(3): p. 1016-1018. DOI: http://dx.doi.org/10.1016/j.desal.2009.09.095.

14. Guirgis, A., R. Gay-de-Montella, and R. Faiz, Treatment of produced water streams in SAGD processes using tubular ceramic membranes. Desalination, 2015. 358: p. 27-32. DOI: http://dx.doi.org/10.1016/j.desal.2014.12.007.

15. Johnson, B.M., Kanagy, L.E., Rodgers, J.H. and Castle, J.W., Chemical, physical, and risk characterization of natural gas storage produced waters. Water Air and Soil Pollution, 2008. 191(1-4): p. 33-54. DOI: 10.1007/s11270-007-9605-8.

16. Engle, M.A., et al., Geochemistry of formation waters from the Wolfcamp and "Cline" shales: Insights into brine origin, reservoir connectivity, and fluid flow in the Permian Basin, USA. Chemical Geology, 2016. 425: p. 76-92. DOI:

10.1016/j.chemgeo.2016.01.025.

17. Arthur, J., B. Langhus, and C. Patel, Technical Summary of Oil \& Gas Produced Water Treatment Technologies, . 2005: Tulsa, Oklahoma, USA.

18. Ahmadun, F.R., Pendashteh, A., Abdullah, L.C., Biak, D.R.A., Madaeni, S.S. and Abidin, Z.Z., Review of technologies for oil and gas produced water treatment. Journal of Hazardous Materials, 2009. 170(2-3): p. 530-551. DOI: 10.1016/j.jhazmat.2009.05.044.

19. Kiss, A.A., S.J.F. Landaeta, and C.A.I. Ferreira, Towards energy efficient distillation technologies - Making the right choice. Energy, 2012. 47(1): p. 531-542. DOI: 10.1016/j.energy.2012.09.038.

20. Thiel, G.P. and J.H. Lienhard V, Treating produced water from hydraulic fracturing: Composition effects on scale formation and desalination system selection. Desalination, 2014. 346: p. 54-69. DOI: http://dx.doi.org/10.1016/j.desal.2014.05.001.

21. Thiel, G.P., Tow, E.W., Banchik, L.D., Chung, H.W. and Lienhard, J.H., Energy consumption in desalinating produced water from shale oil and gas extraction. Desalination, 2015. 366: p. 94-112. DOI: 10.1016/j.desal.2014.12.038.

22. Mistry, K. and J. Lienhard, Generalized Least Energy of Separation for Desalination and Other Chemical Separation Processes. Entropy, 2013. 15(6): p. 2046. 
23. Kalogirou, S.A., Seawater desalination using renewable energy sources. Progress in Energy and Combustion Science, 2005. 31(3): p. 242-281. DOI:

10.1016/j.pecs.2005.03.001.

24. Gude, V.G., N. Nirmalakhandan, and S.G. Deng, Renewable and sustainable approaches for desalination. Renewable \& Sustainable Energy Reviews, 2010. 14(9): p. 2641-2654. DOI: 10.1016/j.rser.2010.06.008.

25. Duong, H.C., Chivas, A.R., Nelemans, B., Duke, M., Gray, S., Cath, T.Y. and Nghiem, L.D., Evaluating energy consumption of air gap membrane distillation for seawater desalination at pilot scale level. Separation and Purification Technology, 2016. 166: p. 55-62. DOI: http://dx.doi.org/10.1016/j.seppur.2016.04.014.

26. Thu, K., Kim, Y.-D., Amy, G., Chun, W.G. and Ng, K.C., A hybrid multi-effect distillation and adsorption cycle. Applied Energy, 2013. 104: p. 810-821. DOI: http://dx.doi.org/10.1016/j.apenergy.2012.12.007.

27. Thu, K., Kim, Y.-D., Shahzad, M.W., Saththasivam, J. and Ng, K.C., Performance investigation of an advanced multi-effect adsorption desalination (MEAD) cycle. Applied Energy, 2015. 159: p. 469-477. DOI: http://dx.doi.org/10.1016/j.apenergy.2015.09.035.

28. Meindertsma, W., W. van Sark, and C. Lipchin, Renewable energy fueled desalination in Israel. Desalination and Water Treatment, 2010. 13(1-3): p. 450-463. DOI: 10.5004/dwt.2010.1004.

29. haffour, N., Lattemann, S., Missimer, T., Ng, K.C., Sinha, S. and Amy, G., Renewable energy-driven innovative energy-efficient desalination technologies. Applied Energy, 2014. 136: p. 1155-1165. DOI: 10.1016/j.apenergy.2014.03.033.

30. Sablani, S.S., Goosen, M.F.A., Paton, C., Shayya, W.H. and Al-Hinai, H., Simulation of fresh water production using a humidification-dehumidification seawater greenhouse. Desalination, 2003. 159(3): p. 283-288. DOI: 10.1016/s0011-9164(03)90080-4.

31. Williams, C.F., Reed, M.J., Mariner, R.H., DeAngelo, J. and Galanis, S.P., Jr., Assessment of moderate-and high-temperature geothermal resources of the United States. 2008: U.S. Geological Survey

32. Goosen, M., H. Mahmoudi, and N. Ghaffour, Water Desalination Using Geothermal Energy. Energies, 2010. 3(8): p. 1423-1442. DOI: 10.3390/en3081423.

33. Gude, V.G., Geothermal source potential for water desalination-Current status and future perspective. Renewable \& Sustainable Energy Reviews, 2016. 57: p. 1038-1065. DOI: 10.1016/j.rser.2015.12.186.

34. Missimer, T.M., et al., Sustainable renewable energy seawater desalination using combined-cycle solar and geothermal heat sources. Desalination and Water Treatment, 2013. 51(4-6): p. 1161-1170.

35. Missimer, T.M., Ng, K.C., Thuw, K. and Shahzad, M.W., Geothermal electricity generation and desalination: an integrated process design to conserve latent heat with operational improvements. Desalination and Water Treatment, 2016. 57(48-49): p. 23110-23118. DOI: 10.1080/19443994.2016.1144693.

36. Kujawa, T., W. Nowak, and A.A. Stachel, Analysis of the exploitation of existing deep production wells for acquiring geothermal energy. Journal of Engineering Physics and Thermophysics, 2005. 78(1): p. 127-135. DOI: 10.1007/s10891-005-0038-1.

37. Kujawa, T., W. Nowak, and A.A. Stachel, Utilization of existing deep geological wells for acquisitions of geothermal energy. Energy, 2006. 31(5): p. 650-664. DOI: 10.1016/j.energy.2005.05.002. 
38. $\mathrm{Bu}, \mathrm{X} . \mathrm{B} ., \mathrm{W} . \mathrm{B}$. Ma, and H.S. Li, Geothermal energy production utilizing abandoned oil and gas wells. Renewable Energy, 2012. 41: p. 80-85. DOI: 10.1016/j.renene.2011.10.009.

39. Wight, N.M. and N.S. Bennett, Geothermal energy from abandoned oil and gas wells using water in combination with a closed wellbore. Applied Thermal Engineering, 2015. 89: p. 908-915. DOI: http://dx.doi.org/10.1016/j.applthermaleng.2015.06.030.

40. Davis, A.P. and E.E. Michaelides, Geothermal power production from abandoned oil wells. Energy, 2009. 34(7): p. 866-872. DOI: http://dx.doi.org/10.1016/j.energy.2009.03.017.

41. Han, C.J. and X. Yu, Sensitivity analysis of a vertical geothermal heat pump system. Applied Energy, 2016. 170: p. 148-160. DOI: 10.1016/j.apenergy.2016.02.085.

42. Templeton, J.D., Ghoreishi-Madiseh, S.A., Hassani, F. and Al-Khawaja, M.J., Abandoned petroleum wells as sustainable sources of geothermal energy. Energy, 2014. 70: p. 366-373. DOI: 10.1016/j.energy.2014.04.006.

43. Cheng, W.-L., Li, T.-T., Nian, Y.-L. and Xie, K., Evaluation of working fluids for geothermal power generation from abandoned oil wells. Applied Energy, 2014. 118: p. 238-245. DOI: 10.1016/j.apenergy.2013.12.039.

44. Noorollahi, Y., Pourarshad, M., Jalilinasrabady, S. and Yousefi, H., Numerical simulation of power production from abandoned oil wells in Ahwaz oil field in southern Iran. Geothermics, 2015. 55: p. 16-23. DOI: 10.1016/j.geothermics.2015.01.008.

45. Kang, M., Kanno, C.M., Reid, M.C., Zhang, X., Mauzerall, D.L., Celia, M.A., Chen, Y.H. and Onstott, T.C., Direct measurements of methane emissions from abandoned oil and gas wells in Pennsylvania. Proceedings of the National Academy of Sciences of the United States of America, 2014. 111(51): p. 18173-18177. DOI:

10.1073/pnas.1408315111.

46. Moran, M.J. and H.N. Shapiro, Fundamentals of engineering thermodynamics: SI version. 2006, Hoboken, NJ: John Wiley. 831.

47. Liu, Q., A.J. Shen, and Y.Y. Duan, Parametric optimization and performance analyses of geothermal organic Rankine cycles using R600a/R601 a mixtures as working fluids. Applied Energy, 2015. 148: p. 410-420. DOI: 10.1016/j.apenergy.2015.03.093.

48. Bergman, T.L. and F.P. Incropera, Fundamentals of heat and mass transfer. 2011, Hoboken, NJ: Wiley.

49. Cheng, W.-L., Huang, Y.-H., Lu, D.-T. and Yin, H.-R., A novel analytical transient heatconduction time function for heat transfer in steam injection wells considering the wellbore heat capacity. Energy, 2011. 36(7): p. 4080-4088. DOI: 10.1016/j.energy.2011.04.039.

50. EIA (2010) Mapping System, U.S. Energy Information Administration (EIA), http://www.eia.gov/maps/

51. DrillingInfo 2016, DrillingInfo Inc., Houston, TX, http://info.drillinginfo.com/

52. SMU (2016) National Geothermal Data System, Southern Methodist University (SMU), Dallas, TX, http://geothermal.smu.edu/gtda/

53. U.S. Geological Survey (2016) National Produced Waters Geochemical Database v2.2, U.S. Geological Survey (USGS) http://energy.usgs.gov/EnvironmentalAspects/EnvironmentalAspectsofEnergyProduction andUse/ProducedWaters.aspx\#3822349-data, 
54. Jong van Lier, Q.d. and A. Durigon, Soil thermal diffusivity estimated from data of soil temperature and single soil component properties. Revista Brasileira de Ciência do Solo, 2013. 37: p. 106-112.

55. ESRI 2012. ArcGIS Desktop: Release 10.1. Redlands, CA: Environmental Systems Research Institute, http://www.esri.com.

56. Texas Water Development Board. (2014) Annual Statewide Water Use, Austin, TX, https://www.twdb.texas.gov/waterplanning/waterusesurvey/estimates/. 
Figure 1. Schematic illustration of a retrofitted geothermal well and its associated closed loop flow system. The working fluid is continuously extracted at high temperatures and re-injected once cooled for re-heating. The produced water stream is treated on the surface and will never be injected into the retrofitted geothermal well or the closed loop flow system. The extracted hot water powers the desalination unit

Figure 2. Texas Oil and Gas Formations

Figure 3. Effect of Model Variables on Deliverable Treated Water

Figure 4. (L) Working fluid injection velocity impact on treated water delivery (R) Projected water delivery capacity over the lifetime of a retrofitted geothermal well

Figure 5. Projected water devliery based on an "Average" scenario. The scenario represents the average depth, average TDS, average geothermal gradient, and average thermal conductivity within each grid cell. Only grid cells where oil and gas wells are present are depicted (wells producing 30,000 L/day meet the daily needs for 92 residential users)

Figure 6. Projected water devliery based on an "Ideal" scenario. This scenario represents the maximum depth, minimum TDS, maximum geothermal gradient, and maximum thermal conductivity within each grid cell. Only grid cells where oil and gas wells are present are depicted (wells producing 30,000 L/day meet the daily needs for 92 residential users) 


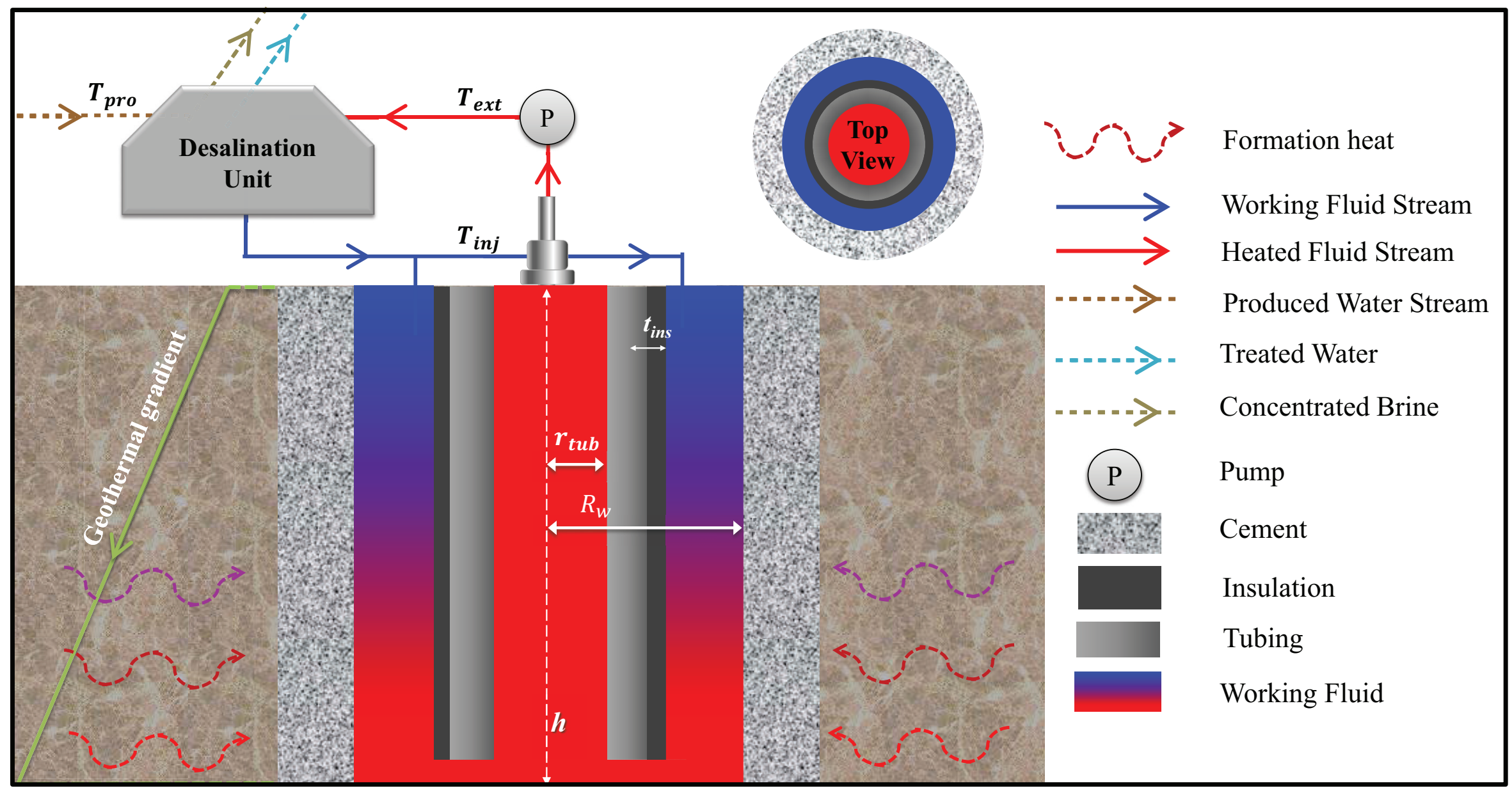




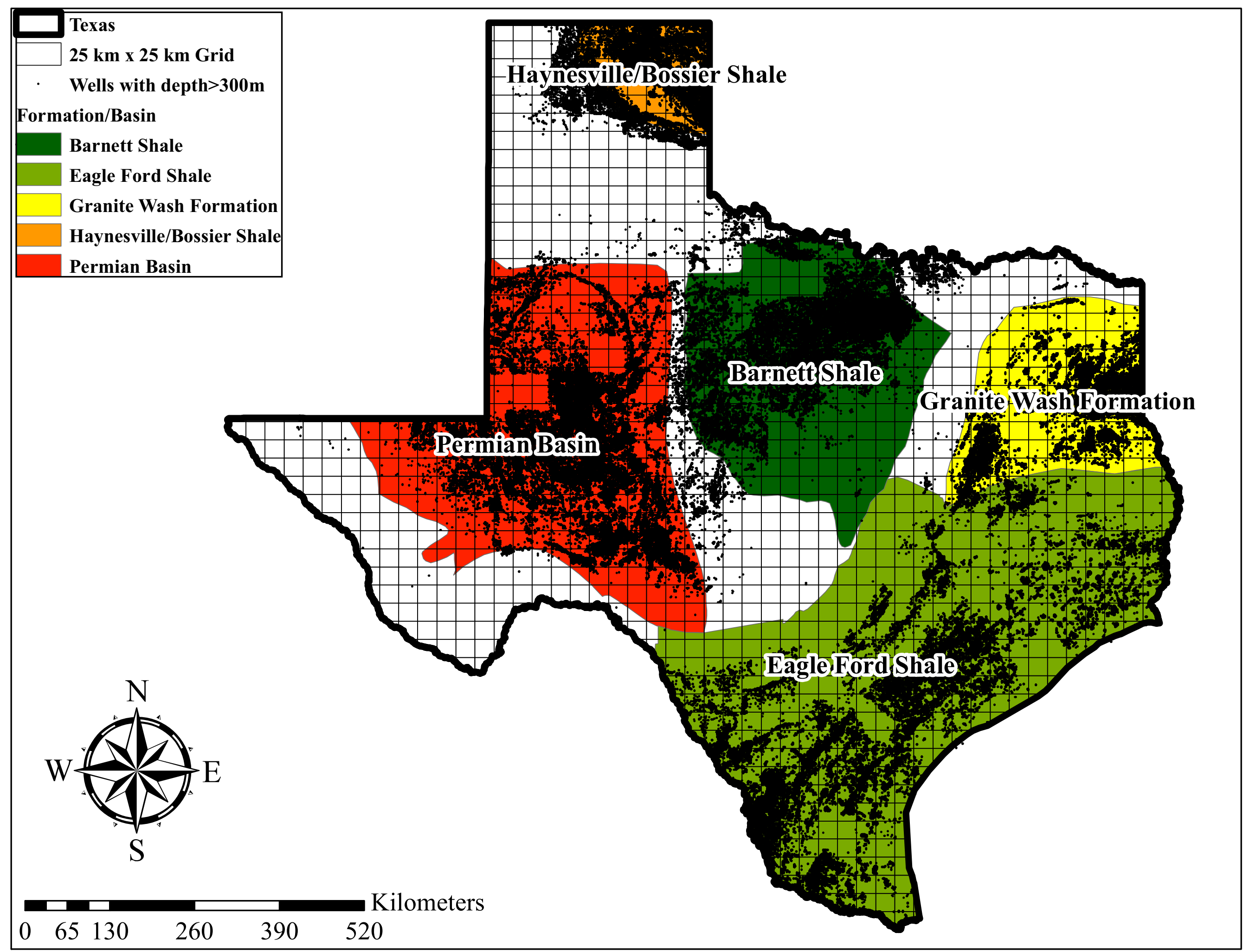




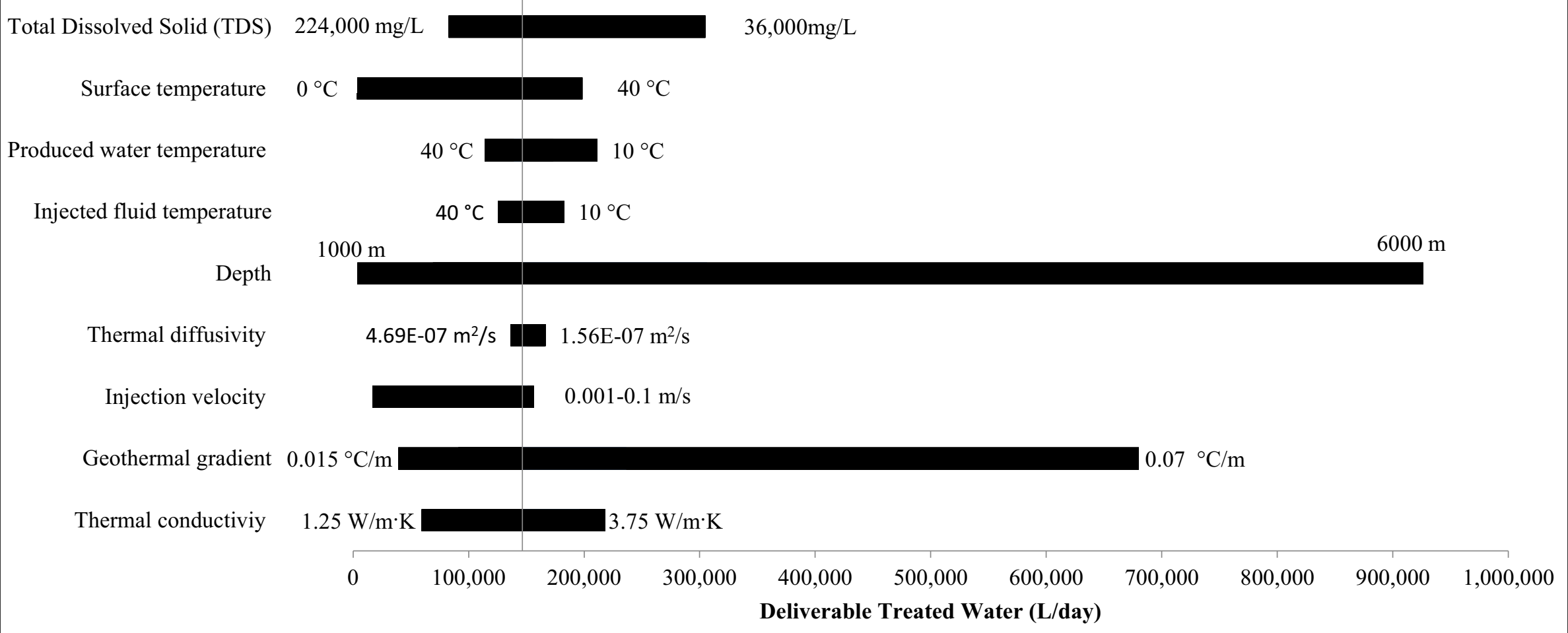

Geothermal gradient $0.015^{\circ} \mathrm{C} / \mathrm{m}$

Geothermal gradient $0.015^{\circ} \mathrm{C} / \mathrm{m}$

Thermal conductiviy 

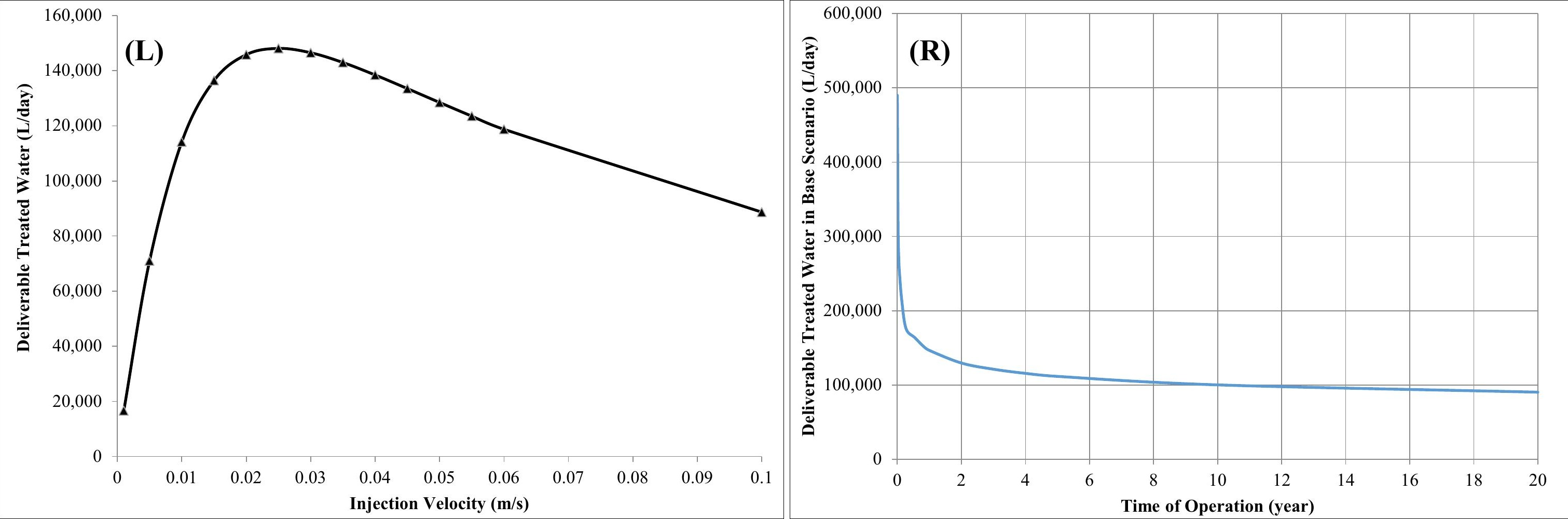


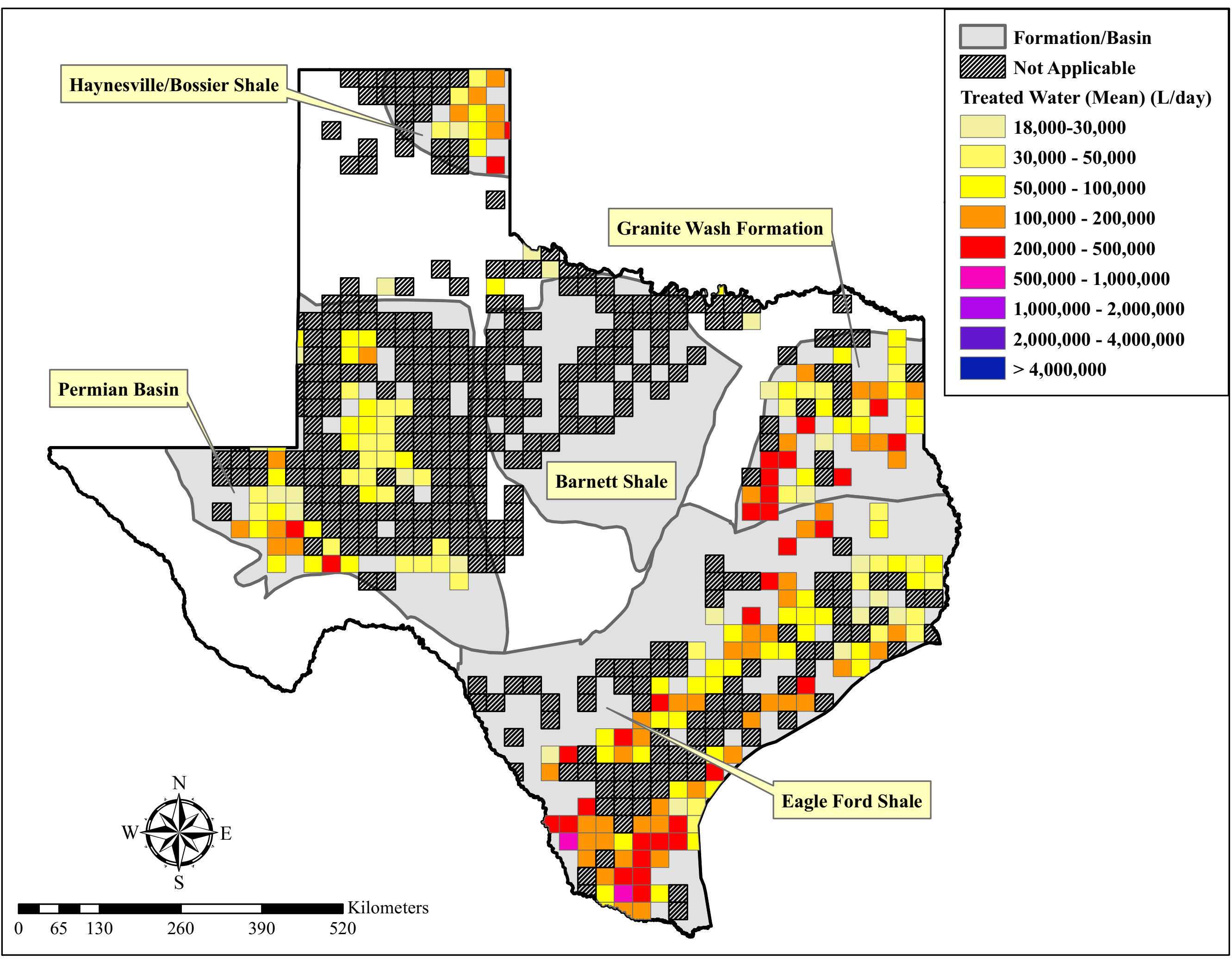




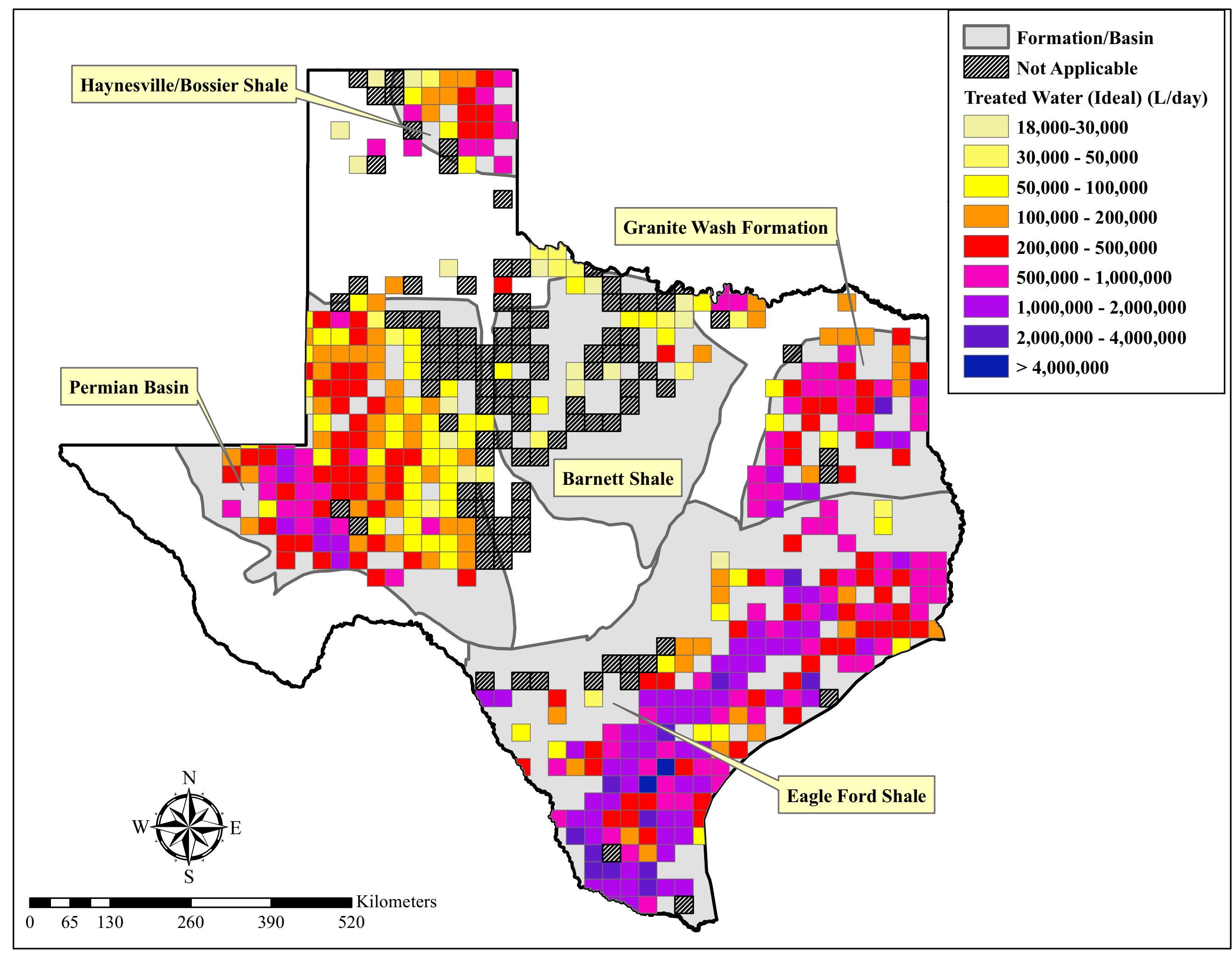


Table 1. Values for base scenario conditions for deliverable water volume modeling

\begin{tabular}{|c|c|c|c|c|c|}
\hline \multirow{2}{*}{ Variable } & \multirow{2}{*}{ Unit } & \multicolumn{3}{|c|}{ Range for Sensitivity Analysis } & \multirow{2}{*}{ Notes } \\
\hline & & Low & $\begin{array}{c}\text { Base } \\
\text { Scenario } \\
\end{array}$ & High & \\
\hline \multicolumn{6}{|c|}{ Formation Properties } \\
\hline$\lambda_{e}$ & $\mathrm{~W} / \mathrm{m} \cdot \mathrm{K}$ & 1.25 & 2.5 & 3.75 & $\begin{array}{l}\text { Formation thermal conductivity, see Section } 2.5 \text { Illustrative Feasibility } \\
\text { Analysis for Texas and equations (2), (7) }\end{array}$ \\
\hline$\nabla e$ & ${ }^{\circ} \mathrm{C} / \mathrm{m}$ & 0.015 & 0.03 & 0.07 & $\begin{array}{l}\text { Geothermal gradient, see Section } 2.5 \text { Illustrative Feasibility Analysis } \\
\text { for Texas and equations (2), (7) }\end{array}$ \\
\hline$\alpha_{e}$ & $\mathrm{~m}^{2} / \mathrm{s}$ & $1.56 \mathrm{E}-07$ & $3.13 \mathrm{E}-07$ & $4.69 \mathrm{E}-07$ & Thermal diffusivity of the formation [54], and equations (2), (5), (7) \\
\hline$T_{\text {surf }}$ & $\mathrm{K}$ & 273 & 303 & 313 & $\begin{array}{l}\text { Surface temperature, see Section } 2.5 \text { Illustrative Feasibility Analysis for } \\
\text { Texas and equations (2), (7) }\end{array}$ \\
\hline \multicolumn{6}{|c|}{ Well Properties } \\
\hline$h$ & $\mathrm{~m}$ & 1000 & 3000 & 6000 & $\begin{array}{l}\text { Depth, see Section } 2.5 \text { Illustrative Feasibility Analysis for Texas and } \\
\text { equations (2), (7) }\end{array}$ \\
\hline$R_{w}$ & $\mathrm{~m}$ & $\mathrm{n} / \mathrm{a}$ & 0.125 & $\mathrm{n} / \mathrm{a}$ & Internal radius of the well [43] \\
\hline$r_{t u b}$ & $\mathrm{~m}$ & $\mathrm{n} / \mathrm{a}$ & 0.05 & $\mathrm{n} / \mathrm{a}$ & External radius of tubing [43] \\
\hline$t_{\text {ins }}$ & $\mathrm{m}$ & $\mathrm{n} / \mathrm{a}$ & 0.01 & $\mathrm{n} / \mathrm{a}$ & Thickness of the insulating layer [43] \\
\hline \multicolumn{6}{|c|}{ Working Fluid Properties } \\
\hline$C_{w f}$ & $\mathrm{KJ} / \mathrm{Kg} \cdot \mathrm{K}$ & $\mathrm{n} / \mathrm{a}$ & 4,179 & $\mathrm{n} / \mathrm{a}$ & Specific heat of working fluid [46] \\
\hline$\mu_{w f}$ & N.s $/ \mathrm{m}^{2}$ & $\mathrm{n} / \mathrm{a}$ & 0.00089 & $\mathrm{n} / \mathrm{a}$ & Working fluid viscosity [46] \\
\hline$\lambda_{w f}$ & $\mathrm{~W} / \mathrm{m} \cdot \mathrm{K}$ & $\mathrm{n} / \mathrm{a}$ & 0.6 & $\mathrm{n} / \mathrm{a}$ & Working fluid thermal conductivity [46] \\
\hline$\rho_{w f}$ & $\mathrm{~kg} / \mathrm{m}^{3}$ & $\mathrm{n} / \mathrm{a}$ & 1,000 & $\mathrm{n} / \mathrm{a}$ & Density of working fluid [46] \\
\hline \multicolumn{6}{|c|}{ Operational Variables } \\
\hline$\tau$ & Days & 1 & 365 & 7000 & $\begin{array}{l}\text { Operation time, see Section } 2.4 \text { Sensitivity Analysis of Heat Transfer } \\
\text { and Deliverable Water Volume and equations (3), (8) }\end{array}$ \\
\hline$u_{w f}$ & $\mathrm{~m} / \mathrm{s}$ & 0.001 & 0.03 & 0.1 & Injection velocity [43], see equations (1), (4), (7) \\
\hline$T_{I n j}$ & $\mathrm{~K}$ & 283 & 303 & 313 & Injected fluid temperature, see equations (1), (3), (4), (7)* \\
\hline$T_{\text {prod }}$ & $\mathrm{K}$ & 283 & 303 & 313 & Produced water temperature, see equations (7), (8)* \\
\hline TDS & $\mathrm{mg} / \mathrm{L}$ & 36,000 & 63,000 & 224,000 & $\begin{array}{l}\text { Total Dissolved Solids, see Section } 2.5 \text { Illustrative Feasibility Analysis } \\
\text { for Texas and equations (7), (8) }\end{array}$ \\
\hline
\end{tabular}

* The temperature of produced water transported to the desalination unit and the temperature of injected water are both assumed to be $30^{\circ} \mathrm{C}(303 \mathrm{~K}) ; \mathrm{n} / \mathrm{a}-\mathrm{not}$ applicable 
Table 2. Summary statistics of well depth, TDS level, and geothermal gradients in Texas formations

\begin{tabular}{|c|c|c|c|c|c|c|c|c|c|c|c|c|}
\hline \multirow{2}{*}{ Formation/Basin } & \multicolumn{4}{|c|}{ Depth (m) } & \multicolumn{4}{|c|}{ TDS (mg/l) } & \multicolumn{4}{|c|}{ Geothermal Gradient $\left({ }^{\circ} \mathrm{C} / \mathrm{m}\right)$} \\
\hline & $\mathrm{n}$ & Max & Mean & Median & $\mathrm{n}$ & Max & Mean & Median & $\mathrm{n}$ & Max & Mean & Median \\
\hline Haynesville/Bossier Shale & 15167 & 7,974 & 2,714 & 2,637 & 234 & 275,915 & 111,882 & 102,759 & 157 & 0.044 & 0.025 & 0.025 \\
\hline Barnett Shale & 42116 & 6,141 & 1,445 & 1,406 & 472 & 300,155 & 146,329 & 154,531 & 894 & 0.046 & 0.026 & 0.026 \\
\hline Permian Basin & 62049 & 8,170 & 2,304 & 2,335 & 5453 & 395,348 & 115,010 & 99,534 & 1045 & 0.044 & 0.024 & 0.023 \\
\hline Granite Wash Formation & 34372 & 6,787 & 2,876 & 3,022 & 1241 & 396,096 & 73,980 & 55,660 & 2427 & 0.067 & 0.036 & 0.035 \\
\hline Eagle Ford Shale & 70540 & 11,595 & 2,308 & 2,250 & 3905 & 398,024 & 50,692 & 32,516 & 6164 & 0.074 & 0.036 & 0.035 \\
\hline
\end{tabular}


Table 3. Water delivery under varying conditions after 1 year of operation

\begin{tabular}{|c|c|c|c|c|c|c|c|}
\hline \multirow[b]{2}{*}{$\begin{array}{l}\text { Scenario } \\
\text { Number }\end{array}$} & \multicolumn{3}{|c|}{ Model Input } & \multicolumn{4}{|c|}{ Model Output } \\
\hline & $\begin{array}{c}\text { Well } \\
\text { Depth } \\
h(\mathbf{m})\end{array}$ & $\begin{array}{c}\text { TDS } \\
(\mathrm{mg} / \mathrm{l})\end{array}$ & $\begin{array}{c}\text { Geothermal } \\
\text { Gradient } \\
\nabla e\left({ }^{\circ} \mathrm{C} / \mathrm{m}\right)\end{array}$ & $\begin{array}{l}\text { Extracted fluid } \\
\text { temperature } T_{E x t} \\
\left({ }^{\circ} \mathrm{C}\right)\end{array}$ & $\begin{array}{c}\text { Extracted } \\
\text { Heat } Q \\
\text { (KWh/day) }\end{array}$ & $\begin{array}{c}\text { Least Heat } \\
\text { Required } \dot{H}_{\text {least }} \\
\left(\mathrm{KWh} / \mathrm{m}^{3}\right)\end{array}$ & $\begin{array}{c}\text { Deliverable Treated } \\
\text { Water Rate } V_{\text {clean }} \\
\text { (L/day) }\end{array}$ \\
\hline 1 & 2,000 & 36,000 & 0.03 & 53 & 2661 & 31 & 85,183 \\
\hline 2 & 2,000 & 36,000 & 0.04 & 61 & 3548 & 24 & 147,960 \\
\hline 3 & 2,000 & 36,000 & 0.05 & 68 & 4435 & 20 & 226,004 \\
\hline 4 & 2,000 & 63,000 & 0.03 & 53 & 2661 & 65 & 40,916 \\
\hline 5 & 2,000 & 63,000 & 0.04 & 61 & 3548 & 50 & 71,075 \\
\hline 6 & 2,000 & 63,000 & 0.05 & 68 & 4435 & 41 & 108,562 \\
\hline 7 & 2,000 & 170,000 & 0.03 & 53 & 2661 & 89 & 29,888 \\
\hline 8 & 2,000 & 170,000 & 0.04 & 61 & 3548 & 68 & 51,917 \\
\hline 9 & 2,000 & 170,000 & 0.05 & 68 & 4435 & 56 & 79,301 \\
\hline 10 & 3,000 & 36,000 & 0.03 & 75 & 5184 & 17 & 304,979 \\
\hline 11 & 3,000 & 36,000 & 0.04 & 90 & 6912 & 13 & 519,775 \\
\hline 12 & 3,000 & 36,000 & 0.05 & 105 & 8639 & 11 & 779,870 \\
\hline 13 & 3,000 & 63,000 & 0.03 & 75 & 5184 & 35 & 146,495 \\
\hline 14 & 3,000 & 63,000 & 0.04 & 90 & 6912 & 28 & 249,667 \\
\hline 15 & 3,000 & 63,000 & 0.05 & 105 & 8639 & 23 & 374,608 \\
\hline 16 & 3,000 & 170,000 & 0.03 & 75 & 5184 & 48 & 107,010 \\
\hline 17 & 3,000 & 170,000 & 0.04 & 90 & 6912 & 38 & 182,370 \\
\hline 18 & 3,000 & 170,000 & 0.05 & 105 & 8639 & 32 & 273,636 \\
\hline 19 & 4,000 & 36,000 & 0.03 & 100 & 8078 & 12 & 692,806 \\
\hline 20 & 4,000 & 36,000 & 0.04 & 124 & 10771 & 9 & $1,158,752$ \\
\hline 21 & 4,000 & 36,000 & 0.05 & 147 & 13464 & 8 & $1,709,415$ \\
\hline 22 & 4,000 & 63,000 & 0.03 & 100 & 8078 & 24 & 332,779 \\
\hline 23 & 4,000 & 63,000 & 0.04 & 124 & 10771 & 19 & 556,607 \\
\hline 24 & 4,000 & 63,000 & 0.05 & 147 & 13464 & 16 & 821,093 \\
\hline 25 & 4,000 & 170,000 & 0.03 & 100 & 8078 & 33 & 243,084 \\
\hline 26 & 4,000 & 170,000 & 0.04 & 124 & 10771 & 26 & 406,591 \\
\hline 27 & 4,000 & 170,000 & 0.05 & 147 & 13464 & 22 & 599,798 \\
\hline
\end{tabular}

Notes: Shading indicates the variables that changed for the various scenarios 


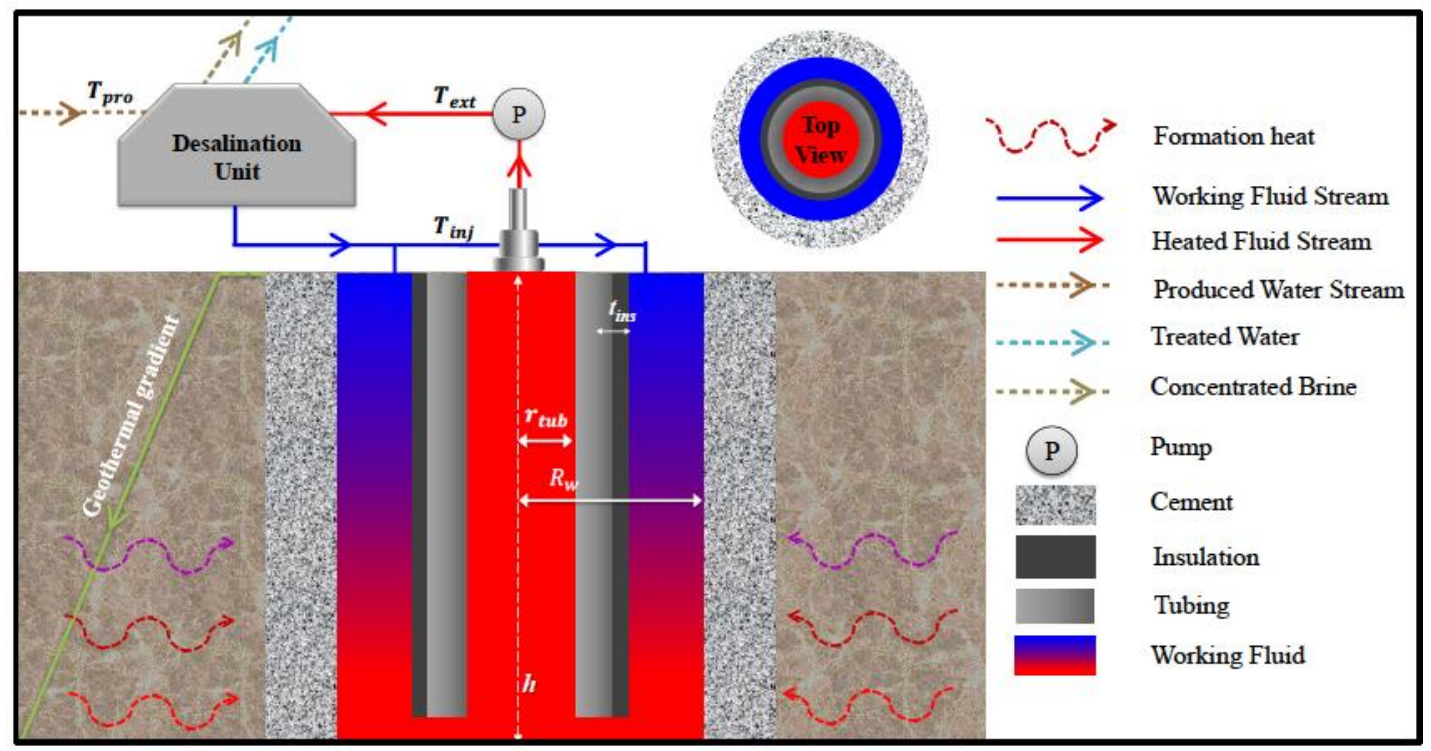

Geothermal energy - desalination system via a retrofitted soon-to-be-shut down oil and gas well can provide sufficient energy to desalinate significant quantities of produced water and generate a sustainable freshwater supply 